\title{
ANTIRETROVIRAL EFFECT OF 4-THIO-URIDYLATE AGAINST HUMAN IMMUNODEFICIENCY VIRUS TYPE 1
}

\author{
SZILVIA KANIZSAI, ÁGOSTON GHIDÁN, JOSEPH ONGRÁdI and KÁROLY NAGY* \\ Institute of Medical Microbiology, Semmelweis University, Budapest, Hungary
}

(Received: 5 October 2012; accepted: 15 October 2012)

\begin{abstract}
Antiretroviral effect of thiolated nucleotide 4-thio-uridylate ( ${ }^{4} \mathrm{UMP}$, designated as UD29) against human immunodeficiency virus type 1 (HIV-1) have been quantitatively determined in cell-based viral infectivity assays. In syntitium inhibition assay on MT-2 human T-cell line UD29 prevented cell fusion and formation of syntitia induced by $\mathrm{HIV}-1_{\text {IIIB }}$ with $\mathrm{IC}_{50}$ values of $11.7 \mu \mathrm{g} / \mathrm{ml}$. In a single-cycle viral infection assay (MAGI assay) UD29 proved to have a potent inhibitory effect against HIV-1 $1_{\text {IIIB }}$ on HeLaCD4-LTR/ $\beta$-gal cells, which was dose dependent with $\mathrm{IC}_{50}$ values of 4.75 $\mu \mathrm{g} / \mathrm{ml}$ and $\mathrm{IC}_{90}$ of $39.7 \mu \mathrm{g} / \mathrm{ml}$. UD29 showed a most prominent antiviral effect when administered 30 min prior HIV-1 infection. As HIV entry requires thiol/disulfide exchange process, results suggest that reactive - $\mathrm{SH}$ group of enol-form of the thiolated nucleotide may interfere with the function of cell surface proteins. UD29 cannot penetrate into cells and may have an interactive role in redox processes active in viral entry.
\end{abstract}

Keywords: HIV infection, thiolated nucleosides, redox system, entry inhibitor, infectivity assays

\section{Introduction}

Human immunodeficiency virus type 1 (HIV-1) infection and AIDS are serious public health issues, as there are more than 35 million people worldwide with HIV-1 infection or AIDS, according to estimates by the Joint United Nations Programme on HIV/AIDS (UNAIDS) [1].

* Corresponding author; E-mail: nagykar@net.sote.hu 
The introduction of highly active antiretroviral therapy (HAART) has dramatically reduced morbidity and mortality of patients infected with HIV-1 [2]. The success of antiretroviral treatment, however, is limited by the emergence of HIV-1 drug resistance, and by the fact that the drugs (which are inhibitors of virally coded enzymes) used so far act only while the virus already infected the cells.

The effort to identify therapeutic targets and develop effective treatment [3] has led to extensive characterization of HIV and a better understanding of its replication cycle. The life cycle of retroviruses, including HIV is divided into two distinct phases: the early phase refers to the steps of infection from cell binding to the integration of the viral cDNA into the cell genome, whereas the late phase begins with the expression of viral genes and continues through to the release and maturation of progeny virions.

The first clinically used effective inhibitor of HIV replication was the nucleoside analogue, azido-thymidine (AZT) inhibiting the virus coded reverse transcriptase (RT); later several other nucleoside analogues were developed with the same mode of action. For sensitive detection of AZT, we have developed a specific radioimmuno-assay [4]. A new class of therapeutic HIV inhibitor was developed, the non-nucleoside RT inhibitors (NNRTI). Later, another HIV enzyme, protease (PR) paved the way for the development of new class of antiviral agents: protease inhibitors [5]. Today these classes of inhibitors are the bases of the HAART that has considerably extended the lifespan of many HIV patients. However, the frequent development of resistance towards these drugs limits their therapeutic application, as we analyzed it recently in Hungary [6, 7].

RT and PR inhibitors target HIV enzymes while virus infection has occurred, and HIV already entered into the susceptible cells. The most effective anti-HIV compounds should inhibit HIV entry into cells [8]. This initiated a more extensive study on the early steps of HIV infection and the virus-cell interactions. However, in comparison with the later events of HIV infection, early steps: HIV entry, the mechanism of receptor binding, conformational changes and fusion are still poorly understood [9]. Fully elucidating the early steps of HIV replication is therefore crucial, not only for identifying new antiretroviral drugs, but also for improving the design of retroviral vectors for gene therapy.

The first step in the primary infection is HIV-1 entry into host cells mediated by its envelope glycoprotein (Env). The mature HIV envelope is composed of the surface glycoprotein (gp)120 and transmembrane gp41 subunits [10]. HIV binding to $\mathrm{CD} 4^{+}$lymphocytes is initiated by gp120 interaction with cell surface CD4 (the primary receptor for HIV), which creates a high affinity binding site on 
gp120 for the chemokine coreceptor CXCR4 (or in the case of macrophages, CCR5) [11]. Interactions between gp120 and the receptors lead to extensive conformational changes within Env that eventually promote the unmasking of the fusion peptide present on gp41. These conformational changes lead to the fusion of viral and cell membranes allowing HIV to get into cytoplasm [12]. An inhibitor of gp41 (Enfuvirtide/T20) has recently been approved for therapeutic use in combination therapy as HIV entry inhibitor [13].

In addition to conformational changes in cell surface receptors, coreceptors of HIV and viral envelope proteins, redox changes in these proteins are also required for successful HIV-1 entry and infection. Several inhibitors of protein disulfide isomerase (PDI) as well as cell-surface-thiol interacting agents including thioredoxin, influence HIV infection $[14,15]$ indicating that redox processes active in viral entry could be potential targets for treatment of HIV infection, as we and others reported earlier [14-18].

In this paper we extend the earlier study on the antiretroviral activity of 4-thio-uridylate (designated as UD29) [16] measuring its inhibitory activity in cell infectivity assays.

\section{Materials and Methods}

Preparation of thiolated uridylate $\left(S^{4} U M P, U D 29\right)$

The 4-thio uridylate (designated as UD29) was prepared by $\mathrm{H}_{2} \mathrm{~S}$ treatment of cytidine 5'-monophosphate, as described for oligonucleotides [18], and was provided by Dr. Janos Aradi, University of Debrecen. A $20 \mathrm{mM}(6.66 \mathrm{mg} / \mathrm{ml})$ aqueous stock solution of UD29 was prepared and kept at $-20^{\circ} \mathrm{C}$. It was diluted to the required concentration with tissue culture media before use. In UD29 the 4-thiono group has a propensity toward tautomeric conversion to form a reactive -SH, which may affect redox processes [16] (see Fig. 1). It is soluble in water, tissue culture fluid, and the solution is stable at $4^{\circ} \mathrm{C}$ for 15 days. Stock solution has been sterilised by filtration. The UD29 solutions are slightly light sensitive.

\section{Cells and viruses}

H9 human T-cell line, MT-2 human T-cell line and HeLaCD4-LTR/ $\beta$-gal cell lines were obtained from the NIH AIDS Research and Reference Reagent Pro- 


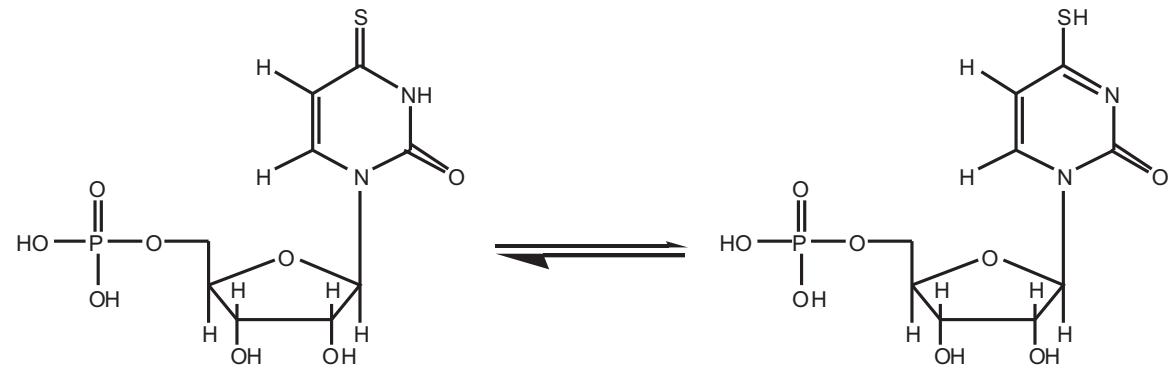

Figure 1. Structure of 4-thio-uridylate (s4UMP, UD29); keto- and enol-tautomers

gram (Bethesda, MD). H9 and MT-2 cell were maintained in RPMI 1640 medium supplemented with $10 \%$ fetal calf serum, $2 \mathrm{mM}$ l-glutamine and antibiotics. HeLaCD4-LTR/ $\beta$-gal cells were cultured in DMEM, $10 \%$ fetal calf serum, $2 \mathrm{mM}$ L-glutamine and antibiotics.

Human immunodeficiency virus type $1\left(\mathrm{HIV}-1_{\mathrm{IIIB}}\right)$ was obtained from R. Weiss (London University, London, UK).

$H I V-1_{\text {IIIB }}$ stocks

The HIV-1 $1_{\text {IIIB }}$ strains were propagated in $\mathrm{H} 9$ human permanent $\mathrm{T}$ lymphocyte cells. HIV-1 $1_{\text {IIIB }}$ stocks were prepared from 24-h supernatants of freshly infected $\mathrm{H} 9$ cells at 4 to 6 days after infection. Infectious titer was determined by infectivity assays on MT-2 human T cells (see below). Supernatants with titers of $2.1 \times 10^{5} \mathrm{IU} / \mathrm{ml}$ were filtered through a $0.45 \mu$ pore size filter (Millipore) and stored at $-70^{\circ} \mathrm{C}$.

\section{HIV-1 infectivity assays}

Syncytium induction and inhibition assays on MT-2 cells

The infectious units of biologically active HIV-1 were determined by their ability to induce syncytia (multinucleated giant cells or big balloon cells) [19, 20] on MT-2 human T-cell line. Cells were cultured in a completed RPMI 1640 medium and seeded in a 24 -well plate $\left(8 \times 10^{4}\right.$ cell/well $)$, and various dilutions of HIV-1 stock (prepared according to our published method [5]) were added. Appearance of syncytia was counted $48 \mathrm{~h}$ post infection. The possible inhibitory ac-

Acta Microbiologica et Immunologica Hungarica 59, 2012 
tivity on syncytia formation of the thiolated compounds (UD29) was quantitatively determined by adding the compounds in various concentrations $(1,2.5,5$, $10,20,40 \mu \mathrm{g} / \mathrm{ml}$, respectively) to the cells $30 \mathrm{~min}$ before, at the time and $30 \mathrm{~min}$ after virus infection. Reduction in the numbers of syncytia compared to the one without UD29 treatment was calculated.

Quantitative HIV-1 p24 core antigen assay

Presence of HIV-1 core protein p24 in the supernatant of MT-2 cells upon infection with HIV-1 stock, and the reduction of the concentration of HIV-1 p24 upon addition of the thiolated nucleotide (UD29) in various concentrations (see above) before, at the time and after HIV-1 infection was quantitatively determined by a HIV-1 p24 core antigen ELISA (BioMérieux, France).

Multinuclear activation of galactosidase inhibition (MAGI) assay

Infectious titer of HIV-1 has also been determined by the MAGI assay, as we previously published [5]. Basically HeLaCD4-LTR/ $\beta$-gal cells was seeded in 24-well plates and infected with a multiplicity of infection (moi) of 0.02, 0.2, and 0.4 , respectively, of HIV-1 stock virus in the presence or in the absence of various concentrations $(1,2.5,5,10,20,40 \mu \mathrm{g} / \mathrm{ml}$, respectively) of UD29 . UD29 was added to the cells $30 \mathrm{~min}$ before, at the time and $30 \mathrm{~min}$ after virus infection. Forty hours after infection, infected cells were counted in situ with light microscope by virtue of their blue color after incubation with 5-bromo-4-chloro-3-indolyl- $\beta$-Dgalactopyranoside (X-gal). Per cent inhibition was calculated as mean numbers of blue cells of inhibitor-treated versus non-treated cultures using Hill analysis.

\section{Statistical methods}

For the determination of UD29 inhibitory concentrations $\mathrm{IC}_{50}$ and $\mathrm{IC}_{90}$ values Hill analysis with $95 \%$ confidence limit was used. For other biostatistical analysis two-tailed Student's test was used.

XTT Assay measuring cytotoxicity

Prior to infectivity assays, the potential toxic effect of UD29 compound on HeLaCD4-LTR/ $\beta$-gal cells has been determined quantitatively in vitro by XTT

Acta Microbiologica et Immunologica Hungarica 59, 2012 
based Toxicology Assay Kit (Sigma-Aldrich), which is a spectrophotometric measurement of cell viability based on mitochondrial dehydrogenase activity in living cells. The mitochondrial dehydrogenases of viable cells reduce the terazolium ring of XTT (2,3-bis/2-Mthoxy-4-nitro5-sulphophenyl/-2H-terazolium-5-carboxyanilide inner salt) yielding an orange formazane derivative. Absorbance of converted dye is measured at a wavelength of $450 \mathrm{~nm}$. During XTT assay to measure cytotoxicity each well contained $125 \mu$ l (DMEM, 10\%FCS, Pen/Str) volume. The incubation period was 48 hours. At test all of the media was removed and $100 \mu \mathrm{l}$ DMEM was added. 20\% of dissolved XTT reagent (Sigma-Aldrich) was added to the media. Incubation time prior to measuring was 2.5 hours. Assay was performed according to the protocol.

\section{Results}

\section{UD29 effect on cell viability}

For analyzing possible antiviral effect of the thiolated uridylate in vitro, its potential cytotoxicity on cell viability was determined on MT-2 human T lymphoid cells as well as quantitatively on HeLaCD4-LTR/ $\beta$-gal cells (Fig. 2). The acute $(24 \mathrm{~h})$ and chronic $(48 \mathrm{~h})$ cytotoxicity of the UD29 compound was determined by XTT Assay (Sigma-Aldrich), that measures metabolic activity, and is

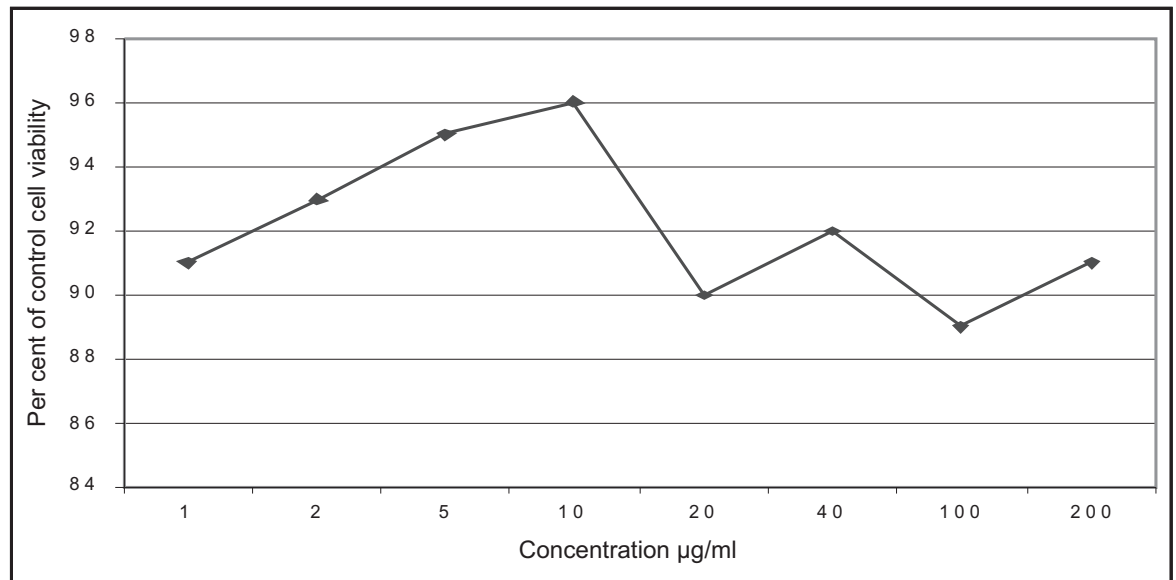

Figure 2. Toxicity of UD29 on HeLaCD4-LTR/ $\beta$-gal cells

UD29 was administered at the indicated concentration to the monolayer cell cultures, and incubated for $48 \mathrm{~h}$. XTT assay, absorbance was read at $450 \mathrm{~nm}$ 
suitable for analyzing proliferation, viability, and cytotoxicity. There was no detectable cytotoxicity (morphologically or by formazan dye reduction) when as high as $200 \mu \mathrm{g} / \mathrm{ml}$ doses were utilized demonstrating that UD29 is a relatively non-cytotoxic nucleotide analogue.

Table I

Inhibitory effect of UD29 on a single cycle infection of HeLaCD4-LTR/ $\beta$-gal cells infected with $\mathrm{HIV}-1_{\text {IIIB }}$

\begin{tabular}{lccc}
\hline $\begin{array}{l}\text { Concentration of UD29 } \\
\mu \mathrm{g} / \mathrm{ml}\end{array}$ & \multicolumn{3}{c}{ \% inhibition $^{\mathrm{a}}$} \\
\cline { 2 - 4 } & $-30 \mathrm{~min}$ & at infection & $+30 \mathrm{~min}$ \\
\hline 1 & 2 & 2 & $<1$ \\
2.5 & 40 & 19 & 2 \\
5 & 46 & 26 & 5 \\
10 & 81 & 32 & 7 \\
20 & 85 & 39 & 8 \\
40 & 91 & 48 & 9 \\
$\mathrm{IC}_{50}$ & $4.75 \mu \mathrm{g} / \mathrm{ml}$ & $>40 \mu \mathrm{g} / \mathrm{ml}$ & $>40 \mu \mathrm{g} / \mathrm{ml}$ \\
$\mathrm{IC}_{90}$ & $39.7 \mu \mathrm{g} / \mathrm{ml}$ & $>40 \mu \mathrm{g} / \mathrm{ml}$ & $>40 \mu \mathrm{g} / \mathrm{ml}$ \\
\hline
\end{tabular}

${ }^{a}$ Inhibitor was added to the cultures at indicated time intervals before, at the time and after infection with virus. $\beta$-galactosidase enzyme expression was quantitatively determined (see Materials and Methods), and per cent inhibition was calculated using Hill analysis. Results are representative of multiple antiviral assays with values shown as means of triplicates. Standard deviation was $\pm 5.8 \%$.

Antiviral activity of UD29 in cell based infectivity assays in vitro

Inhibition of cell fusion on MT-2 cells

When added to MT-2 human T-cells 30 min prior infection with HIV-1 $1_{\text {IIIB }}$ strain, UD29 prevented formation of syncytia (multinucleated giant cell and/or "balloon" cells without cell structures) (Fig. 3). Quantitative determination of HIV-1 p24 core protein in the supernatant of virus infected MT-2 cells with and without treatment of indicated UD29 concentrations demonstrated that UD29 showed an activity on inhibition of HIV-1 ${ }_{\text {IIIB }}$ induced cell fusion with $\mathrm{IC}_{50}$ values of $11.7 \mu \mathrm{g} / \mathrm{ml}$ (Table II).

Inhibitory effect of UD29 on a single cycle infection with HIV-1 ${ }_{\text {IIIB }}$ of HeLaCD4-LTR/ $\beta$-gal cells

Now inhibition of HIV-1 replication by UD29 was assessed in standard cell-based assay, such as the MAGI assay. HeLaCD4-LTR/ $\beta$-gal cells have been 


\section{Table II}

Antiviral activity of UD29 against HIV-1 $1_{\text {IIIB }}$ : assessment for inhibition cell fusion and virus entry

\begin{tabular}{lccc}
\hline & $\mathrm{IC}_{50}{ }^{\mathrm{a}}$ & $\mathrm{TC}_{50}{ }^{\mathrm{b}}$ & $\mathrm{TI}^{\mathrm{c}}$ \\
\hline Cell fusion & $11.7 \mu \mathrm{g} / \mathrm{ml}$ & $>200$ & $>17$ \\
Viral entry $^{\mathrm{d}}$ & $4.75 \mu \mathrm{g} / \mathrm{ml}$ & $>200>42$ & \\
\hline
\end{tabular}

${ }^{\text {a }} 50 \%$ inhibition of virus infection

${ }^{\mathrm{b}} 50 \%$ reduction in cell viability

${ }^{c}$ In vitro therapeutic index

${ }^{\mathrm{d}}$ In MAGI assay

treated with various concentration of UD29 $(1-40 \mu \mathrm{g} / \mathrm{ml}) 30 \mathrm{~min}$ before, at the time and 30 min after infection of cells with HIV-1 $1_{\text {IIIB }}$ virus of $0.02,0.2$, and 0.4 moi. HeLa cell construct allows only a single cycle of virus infection, therefore it is suitable to test compounds with a potential of inhibiting viral entry. Forty hours after virus infection $\beta$-galactosidase enzyme expression was quantitatively determined (see Materials and Methods), and per cent inhibition as well as $\mathrm{IC}_{50}$ and $\mathrm{IC}_{50}$ values were calculated using Hill analysis. UD29 showed a most prominent antiviral effect when administered 30 min prior to HIV-1 infection (Table I). UD29 proved to have a potent inhibitory effect against HIV-1 $1_{\text {IIIB }}$ on HeLaCD4$\mathrm{LTR} / \beta$-gal cells, which was dose dependent with $\mathrm{IC}_{50}$ values of $4.75 \mu \mathrm{g} / \mathrm{ml}$ and $\mathrm{IC}_{90}$ of $39.7 \mu \mathrm{g} / \mathrm{ml}$ (Table I). It was noted, that its antiviral activity was more pronounced in the infectivity (MAGI) assay than UD29 inhibitory effect on cell fusion (Table II).
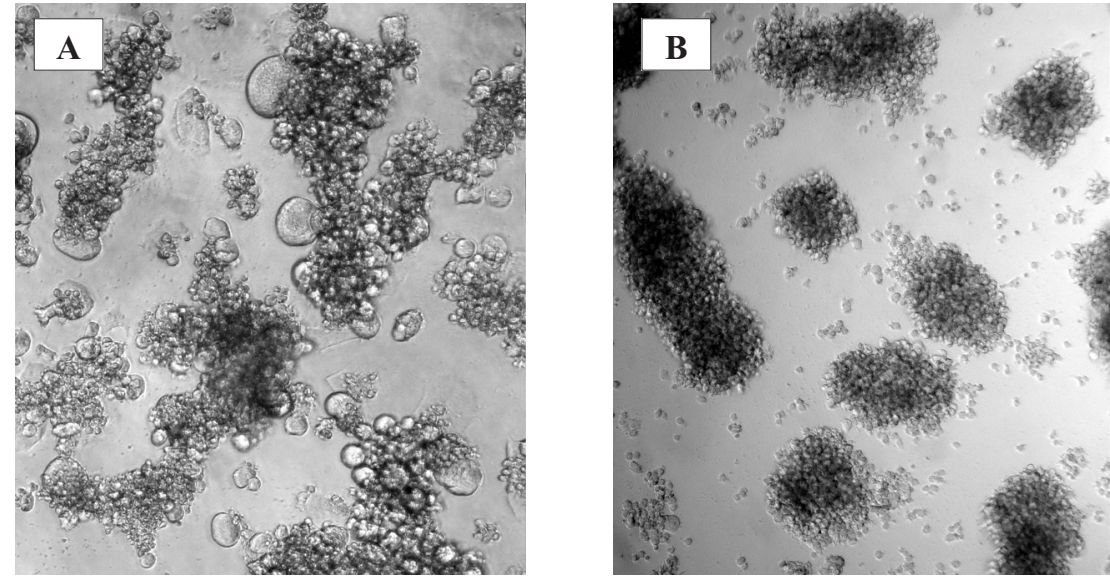

Figure 3. Inhibition of formation of syntitia (arrows) i.g. HIV-1 $1_{\text {IIIB }}$ virus infected MT-2 cells upon treatment with UD29. A: virus infected, untreated cells, B: MT-2 cells treated with UD29 $(10 \mu \mathrm{g} / \mathrm{ml}) 30 \mathrm{~min}$ prior to viral infection. No syncyitia were formed 


\section{Discussion}

To elucidate the exact inhibitory mechanism of UD29 a time-of-addition experiment was performed. This experimental approach was able to specifically identify the stages of viral life cycle targeted by thiolated uridylate, UD29. It was shown that maximal inhibitory activity was observed when the drug (UD29) was added prior to HIV-1 infection, in both syntitium, and in infectivity (MAGI) assays. When UD29 was added after virus infection its inhibitory activity was reduced significantly (Table I). This result suggests that the inhibitory activity on virus infection was exerted during early stage of viral life cycle, most likely, in the entry process. Moreover, as UD29 is a nucleotide, its cellular uptake is not likely, it cannot penetrate into the cells, therefore its activity should be associated with events on the cell surface, virus-cell binding, and/or the entry.

In addition to conformational changes in cell surface receptors, coreceptors of HIV (CD4, CCR5, and CXCR4) and viral envelope proteins (gp120, gp41), redox changes in these proteins are also required for successful HIV entry [21-28]. Specifically, (1) the reduction of the second domain of CD4 was reported to be an obligatory step in CD4-dependent fusion [25]; (2) two of the nine disulfide bonds of gp120 must be reduced in order to promote the successful HIV entry [23, 28]. UD29 is chemically a thiolated nucleotide, in which the enol form of the compound (Fig. 1) contains a reactive-SH group. It was shown earlier that UD29 is an inhibitor of glyceraldehyde-phosphate dehydrogenase (GAPDH) [16], likely interfering with the function of the essential -SH group in the active centre of the enzyme. The interfering effect of the -SH group of the nucleotide with protein -SHs could be the bases of the HIV entry inhibitory activity of UD29, verified by our time-of-addition experiment. UD29 may affect the redox changes of the second domain of CD4 and/or the proper reduction of the disulfide bonds of gp120. The proposed mode of action is in good agreement with results of the time-of-addition experiments and with the syncytia formation assay. The formation of syncytia requires active membrane reorganization in which cell membrane redox processes are likely to be also involved.

It must be noted that UD29 is a mononucleotide, however, its deoxyoligonucleotide derivatives are also active biologically inhibiting the HIV entry and the telomerase enzyme $[18,29,30]$. Preliminary results on the activity of some other derivatives of the thiolated nucleotide and polynucleotide have also been reported [31]. 
In summary, UD29 is a new HIV entry inhibitor acting on the cell surface, likely affecting the redox modifications of receptors and viral proteins. This mechanism has not been exploited yet for the treatment of HIV infection.

\section{Aknowledgement}

This work was supported OTKA 81367 Research Grant. The UD29 was prepared and kindly donated by Dr. Janos Aradi, University of Debrecen.

\section{References}

1. Nagy, K., Albert, J., Bánhegyi, D. (1988): Isolation of HIV from Hungarian AIDS and ARC patients. Laboratóriumi Diagnosztika 15(4), 213-216 (1988). (in Hungarian)

2. Wittinghoff, E., Scheer, S., O’Malley, P., Colfax ,G., Holmberg, S. D., Buchbinder, S. P.: Combination antiretroviral therapy and recent decline in AIDS incidence and mortality. J Infect Dis 179(3), 717-720 (1999).

3. Albert, J., Abrahamson, B., Nagy, K., Aurelius, E., Gaines, H., Nyström, G., Fenyö, E.-M.: Rapid development of isolate-specific neutralizing antibodies after primary HIV-1 infection and consequent emergence of virus variants which resist neutralization by autologous sera. AIDS 4, 107-113 (1990).

4. Cox, S., Rudén, U., Nagy, K., Albert, J., Sandström, E., Holmbergm V., Wahren B.: Serum levels and catabolism of 3'-azido-3'-deoxythymidine in vivo measured using a specific radioimmunoassay. J Virol Meth 30, 89-98 (1990).

5. Nagy, K., Young, M., Baboonian, C., Merson, J., Whittle, P., Oroszlan, S.: Antiviral activity of human immunodeficiency virus type 1 protease inhibitors in a single cycle of infection: evidence for a role of protease in the early phase. J Virol 68, 757-765 (1994).

6. Juhász, E., Ghidán, Á., Kemény, B., Nagy, K.: Emergence of antiretroviral drug resistance in therapy-naive HIV infected patients in Hungary. Acta Microbiol Immunol Hung 55(4), 383-394 (2008).

7. Kanizsai, S., Ghidán, Á., Ujhelyi, E., Bánhegyi, D., Nagy, K.: Monitoring of drug resistance in therapy-naive HIV infected patients and detection of African HIV subtypes in Hungary. Acta Microbiol Immunol Hung 57(1), 55-68 (2010).

8. Nagy, K.: HIV pseudovirions assay for coreceptor selection and entry fitness. In Fust, G. (ed.), Proc. HIV Correlates, June 5-7, Budapest, 2007, p. 12.

9. Nisole, S., Saib, A.: Early steps of retrovirus replication cycle. Retrovirology I 9, 1-20 (2004).

10. Einfeld, D.: Maturation and assembly of retroviral glycoprotein. Curr Top Microbiol 214, 133-176 (1996).

11. Kemény, B., Nagy, K., Horváth, A.: CCR5 and SDF1 gene polymorphism in HIV-infected and healthy individuals in Hungary. Hung Venerol Arch 4(2-3), 89-92 (2000).

12. Berger, E. A., Murphy, P. M., Farber, J. M.: Chemokine receptors as HIV-1 coreceptors: Roles in viral entry, tropism, and disease. Annu Rev Immunol 17, 657-700 (1999). 
13. Kilby, J. M., Eron, J. J.: Novel therapies based on mechanism of HIV-1 cell entry. N Engl J Med 348, 2228-2238 (2003).

14. Ryser, H. J., Levy, E. M., Mandel, R., DiSciullo, G. J.: Inhibition of human immunodeficiency virus infection by agents that interfere with thiol-disulfide interchange upon virus-receptor interaction. Proc Natl Acad Sci USA 91, 4559-4563 (1994).

15. Horváth, A., Beck, Z., Bardos, T. J., Dunn, J. A., Aradi, J.: Effect of the extent of thiolation and introduction of phosphorothioate internucleotide linkages on the anti-HIV activity of Suligovir $\left[\left(\mathrm{s}^{4} \mathrm{dU}\right)_{3}\right]$. Bioorg Med Chem Lett 16, 5321-5323 (2006).

16. Beck, Z., Kis, A., Berenyi, E., Kovacs, P., Fesüs, L.. Aradi, J.: 4-Thio-uridylate (UD29) interferes with the function of protein $-\mathrm{SH}$ and inhibits HIV replication in vitro. Pharmacol Reports 61, 343-347 (2009).

17. Tőkés, S., Aradi, J.: $\left(\mathrm{s}^{4} \mathrm{dU}\right)_{35}$ : A novel highly potent oligonucleotide inhibitor of the human immunodeficiency virus type 1 reverse transcriptase. FEBS Letter 396, 43-46 (1996).

18. Horváth, A., Tőkés, S., Hartman, T., Watson, K., Turpin, J. A., Buckheit, Jr. R. W., Sebestyén, Z., Szöllősi, J., Benkő, I., Bardos, T. J., Dunn, J. A., Fésüs, L., Tóth, F. D., Aradi, J.: Potent inhibition of HIV-1 entry by Suligovir $\left(s^{4} \mathrm{dU}\right) 3$. Virology 334, 214-223 (2005).

19. Nagy, K., Clapham, P., Cheingsong-Popov, R., Weiss, R. A.: Human-T-cell leukemia virus type I: Induction of syncytia and inhibition by patients' sera. Int J Cancer 32, 321-328 (1983).

20. Clapham, P., Nagy, K., Cheingsong-Popov, R., Exley, M., Weiss, R. A.: Productive infection and cell-free transmission of human T-cell leukemia virus in a non-lymphoid cell line. Science 222, 1125-1127 (1983).

21. Leonard, C., Spellman, M. W., Riddle, L., Harris, R., Thomas, J., Gregory, T. J.: Assignment of intrachain disulfide bonds and characterization of potential glycosylation sites of the type 1 recombinant human immunodeficiency virus envelope glycoprotein (gp120) expressed in Chinese hamster ovary cells. J Biol Chem 265, 10373-10382 (1990).

22. Doms, R. W., Peipert, S. C.: Unwelcomed guests with master keys: How HIV uses chemokin receptors for cellular entry. Virology 235, 179-190 (1997).

23. Barbouche, R., Miquelist, R., Jones, I. M., Fenouillet, E.: Protein-disulphide isomerase-mediated reduction of two disulfide binds of HIV envelope glycoprotein 120 occurs post-CXCR4 binding and is required for fusion. J Biol Chemistry 278, 3131-3136 (2003).

24. Fenouillet, E., Barbouche, R., Courageot, J., Miquelis, R.: The catalytic activity of protein disulfide isomerase is involved in human immunodeficiency virus envelope-mediated membrane fusion after CD4 cell binding. J Infect Dis 183, 744-752 (2001).

25. Matthias, L. J., Yam, P. T., Jiang, X. M., Vandegraaff, N., Li, P., Poumbourios, P., Donoghue, N., Hogg, P. J.: Disulfide exchange in domain 2 of CD4 is required for entry of HIV-1. Nat Immunol 3, 727-733 (2002).

26. Ou, W., Silver, J.: Role of protein disulfide isomerase and other thiol-reactive proteins in HIV-1 envelope protein-mediated fusion. Virology 350, 406-417 (2006).

27. Markovic, I., Stanchev, T. S., Fields, K. H., Tiffany, L. J., Tomic, M., Weiss, C. D., Broder, C. C. et al.: Thiol/disulfide exchange is a prerequisite for CXCR4-tropic HIV-1 envelope-mediated T-cell fusion during viral entry. Blood 103, 1586-1594 (2004).

28. Wilen, C. B., Tilton, J. C., Doms, R. W.: Molecular mechanism of HIV entry. In Rossmann, M. G., Rao, V. B. (Eds), Advances in Experimental Medicine and Biology. Springer, 2012.

29. Szatmari, I., Tőkés, S., Dunn, C. B., Bardos, T., Aradi, J.: Modified telomeric repeat amplification protocol: A quantitative radioactive assay for telomerase without using electrophoresis. Anal Biochem 282, 80-88 (2000). 
30. Tarkanyi, I., Horvath, A., Szatmari, I., Eizert, H., Vamosi, G., Damjanovich, S., Segal-Bendirdijan, E., Aradi, J.: Inhibition of human telomerase by oligonucleotide chimeras, composed of an antisense moiety and a chemically modified homooligonucleotide. FEBS Lett 579, 1411-1416 (2005).

31. Kanizsai, Sz., Juhász, E., Ghidán, Á., Aradi, J., Nagy, K.: Antiretroviral effect of poly-thiolated compounds as HIV entry inhibitors. Acta Microbiol Immunol Hung 56(3), Suppl. 2nd CEFORM, p. 57 (2009). 